\title{
Representações interculturais de gênero no romance $A$ república dos sonhos, de Nélida Piñon
}

Lúcia Osana Zolin ${ }^{1}$

O romance A república dos sonhos (1984), de Nélida Piñon, no decorrer de suas 760 páginas, divididas em 37 partes, apresenta uma história que une a saga de uma família que imigra da Espanha para o Brasil no início do século XX aos principais acontecimentos históricos do país. A narrativa abarca eventos que vão desde a infância do protagonista Madruga, nascido em 1900 na Espanha, passando pela sua chegada ao Brasil, em 1913, até sua ascensão como negociante e o destino de sua família 70 anos depois, em 1983. Ao lado da trajetória de Madruga, contempla densas reflexões político-culturais relacionadas às nações que servem de cenário à trama. No que diz respeito ao Brasil, os principais fatos políticos do século $X X$ são intercalados com reflexões que remetem às raízes do autoritarismo e à escravidão, que marcaram o século XIX. Acerca da Espanha, há considerações sobre a perda gradual da identidade cultural do povo galego e do povo cigano sob o domínio de Castela, e sobre a guerra civil espanhola, com a vitória da ditadura de Franco. Nas palavras da escritora, trata-se de sua "suma teológica. Conta a história desse país nos últimos cem anos, mas, mais do que isso, conta a história das utopias europeias em relação à Europa e também da utopia brasileira inventada por seus brasileiros" (Piñon apud Proença Filho, 1998, p. 4).

É em meio a esse espírito de retorno às origens que a saga familiar é narrada através do tempo e do espaço (Espanha e Brasil nos séculos XIX e $X X)$, em um período de sete dias, no qual Eulália, a mulher do patriarca, agoniza na mansão da família no Rio de Janeiro: "Eulália começou a morrer na terça-feira" (p. 7). Essa é a frase que abre o romance e que de certa forma vai gerar todo o seu estatuto temporal.

Interessa-nos, na presente abordagem desse importante romance brasileiro do século XX, perscrutar o modo como a escritora brasileira, em diálogo com a tradição cultural espanhola - cujos valores foram agregados na sua formação ${ }^{2}$-, representa aí identidades femininas e relações de

\footnotetext{
${ }^{1}$ Doutora e pós-doutora em letras e professora do Departamento de Letras e do Programa de PósGraduação em Letras da Universidade Estadual de Maringá (UEM), Maringá, Paraná, Brasil. E-mail: luciazolin@yahoo.com.br.

2 Conforme se pode ler no site oficial da escritora, Nélida Piñon é filha de Olivia Carmen Cuiñas Piñon, brasileira filha de galegos, e Lino Piñon Muiños, comerciante, natural de Borela, município de Cotobade (Galiza). Na década de 1910, seu avô materno, Daniel Cuiñas, chega de Carballedo
} 
gênero. Nesse sentido, a noção de representação, a exemplo do que vem acontecendo no âmbito dos estudos literários contemporâneos - de modo especial, dos estudos de gênero -, parece-nos de fundamental importância.

Trata-se de um conceito que aponta para significações múltiplas, entre elas, para o ato de fazer as vezes da realidade representada; ou para o de tornar uma realidade visível, exibindo-lhe a presença (Ginzburg, 2001). De acordo com Chartier, a representação é "instrumento de um conhecimento mediador que faz ver um objeto ausente através da substituição por uma imagem capaz de o reconstituir em memória e de o figurar como ele é" (Chartier, 1990, p. 10). As representações são variáveis e determinadas pelos grupos ou pelas classes que as edificam, sendo que o poder e a dominação estão sempre presentes. Também para Bourdieu (1998), uma das principais problemáticas que envolvem a questão da representação reside nas imposições e lutas pelo monopólio da visão legítima do mundo social. O fato é que a identidade do ser ou da coisa representada, não raro, se resume à aparência dela, escamoteada que está por configurações intelectuais múltiplas, por meio das quais a realidade é contraditoriamente construída.

Se representar significa dar visibilidade ao outro, no dizer de Chartier (1990), pode significar, também, falar em nome do outro. Para ter assegurado o direito de falar, enquanto o outro é silenciado, o sujeito que fala se investe de um poder que lhe é doado por circunstâncias legitimadas pelo lugar que ocupa na sociedade, delimitado em função de sua classe, de sua raça e de seu gênero, entre outros referentes que o definem como o centro, a referência, o paradigma, enfim, do discurso proferido. Historicamente, esse sujeito imbuído do direito de falar - e falar com autoridade - é de classe média ou alta, branco e pertencente ao sexo masculino.

A crítica literária feminista, bem como o feminismo entendido como pensamento social e político da diferença, surge nesse contexto com o intuito de desestabilizar a legitimidade da representação, ideológica e tradicional, da mulher na literatura canônica. Em A política sexual (1970), Kate Millett desencadeou esse processo, promovendo o desnudamento das práticas discursivas patriarcais de escritores canônicos como Norman Mailer, Henry Miller e David Lawrence. Também no Brasil, a produção

(Cotobade) “para conquistar o Brasil”. Aos dez anos, Nélida muda-se com os pais e os avós maternos para Borela, onde ficam por dois anos. Para a menina urbana, a aldeia galega é uma descoberta e um encantamento. A forte presença da natureza, o modo de vida camponês e, sobretudo, o imaginário galego iriam se infiltrar, mais tarde, na matéria de sua ficção. Nas suas palavras: "Para esta Galícia fui levada menina, quando aprendi suas lendas, sua língua. Assimilei sua poderosa oralidade, pois ali é o território onde as histórias, uma vez iniciadas, não merecem parágrafo”. Disponível em: <www. nelidapinon.com.br>. 
literária canônica foi e ainda tem sido constantemente revisitada por críticos/as feministas com o intuito de questionar e destronar os mecanismos de funcionamento das representações estereotipadas da mulher, cuja imagem aparece associada a forças naturais, ora preza à nobreza de sentimentos e ao caráter elevado, ora relacionada com a Eva pecadora e sensual, tudo remetendo a um maniqueísmo reducionista que em nada condiz com as reais e múltiplas identidades femininas que povoam nossa realidade.

A ideologia que subjaz à construção de $A$ república dos sonhos parece claramente calcada no pensamento feminista que, por volta de meados do século passado, se disseminou no mundo ocidental. Ao engendrar as representações das mulheres que constituem a família do protagonista Madruga, a escritora se afasta das imagens femininas estereotipadas que povoam, frequentemente, a literatura canônica e o imaginário coletivo derivado do pensamento patriarcal, para, em seu lugar, edificar outras, marcadas pela heterogeneidade das identidades femininas de inspiração mais realista.

Ao narrar em A república dos sonhos a saga do imigrante Madruga e de sua família desde a chegada daquele ao Brasil no início do século, Nélida Piñon, num certo sentido, narra também, por meio das representações das mulheres que compõem a trama, a história da emancipação feminina (Zolin, 2003). Tal história, embora não seja explicitamente declarada, aparece diluída ao longo do romance, alicerçando e compondo as trajetórias das várias gerações de mulheres que se fizeram presentes na vida do protagonista: a avó, a mãe, a esposa, as filhas, as noras e a neta, além da agregada.

Tais figuras femininas acabam por constituir um grande painel em que se pode vislumbrar: de um lado, as personagens principais representando os diversos estágios por que passou a mulher até atingir o grau de emancipação que a vemos desfrutar em meados dos anos 1980, o momento presente da narrativa; e, de outro, as personagens secundárias, ora preparando o ambiente em que florescerão as ações daquelas, ora lhes servindo de contraponto.

Trata-se de um elenco de figuras femininas marcadas pela pluralidade e/ou pela diferença identitária que desautoriza qualquer tentativa de lhes conferir unidade sob o rótulo de, simplesmente, "mulheres", no sentido tomado pelo estruturalismo, responsável pela divisão da humanidade em dois polos: o feminino e o masculino - consequentemente, homens $v s$. mulheres, dominantes vs. dominadas, opressores vs. oprimidas. Segundo Judith Butler, "se alguém 'é' uma mulher, isso certamente não é tudo o 
que esse alguém é" (2003, p. 20). Isso porque, segundo a teórica estadunidense pós-estruturalista, não há unidade na categoria mulheres. Trata-se de uma categoria desessencializada, ou seja, sem identidade fixa, sempre em processo, cuja evolução é afetada pelo entrecruzamento com outros eixos, além do gênero, como raça, classe, sexualidade, etnia, etc..

Nesse grande painel das figuras femininas que constituem o romance de Piñon, figuram realidades femininas múltiplas e disformes, que vão desde a campesina oitocentista, representante das mais tradicionais raízes galegas (Teodora, a avó paterna do protagonista), até a mulher liberada dos anos 1980, capaz de se fazer respeitar, qualquer que seja a sua vontade (Breta, a neta). Passam ainda: pela contraparente daquela, marcada pelo desejo de transcender a realidade disfórica do tempo, ainda que por intermédio do filho (Urcesina, a mãe); depois, já no século XX, por uma mulher mais refinada, entretanto, mantida "protegida", pelo pai e pelo marido, dos perigos de viver, bem ao estilo patriarcal (Eulália, a esposa); e, a seguir, pela mais autêntica representante do inconformismo em relação ao modo de estar da mulher nessa sociedade, construída sobre os alicerces do patriarcalismo (Esperança, a filha mais velha).

Embora esse painel de representações femininas, marcado pela multiplicidade e pela heterogeneidade, seja construído através do tempo, entre meados do século XIX e transcorrer do XX, a questão temporal não é a única marca de diversidade e de descentramento reconhecível nas identidades enfocadas. Muito além dela, as personagens referidas mostram-se, não raro - por meio de práticas e reminiscências -, divididas, incoerentes, capazes de, ao mesmo tempo, render tributo às origens culturais da família e de subvertê-las.

De certa forma, trata-se de uma espécie de resposta subversiva às ideologias conservadoras responsáveis pela representação da mulher na literatura canônica segundo um viés tradicional, calcado no maniqueísmo (santas ou pecadoras) e no essencialismo (fracas, submissas, dominadas e resignadas). A escritora faz emergir, por meio do descentramento das identidades representadas, o colapso da concepção de identidade moderna, baseada na herança essencialista do Iluminismo, que pressupunha um sujeito centrado, unificado e completo, sempre idêntico a si mesmo. Para Stuart Hall , tais identidades seguras e coerentes são uma fantasia: "Ao invés disso, à medida que os sistemas de significação e representação cultural se multiplicam, somos confrontados por uma multiplicidade desconcertante e cambiante de identidades possíveis, com cada uma das quais poderíamos nos identificar - ao menos temporariamente" (Hall, 2006, p. 13). 
Assim é que, no núcleo galego, composto por Teodora, Urcesina e Eulália, mesmo sem ter como referencial os sistemas de significação e de representação referidos por Hall (2006), típicos da chamada pós-modernidade, tais personagens são construídas de modo a dar mostras da dificuldade em tomar para si a ideia de coerência que os sistemas sociais em que se inserem lhes conferem.

Embora Teodora aparentemente mostre-se sem qualquer vocação para a transcendência, centrada que é na realidade opressora da época em que está ambientada - sugerindo a unidade identitária atribuída ao "sujeito do iluminismo" a que se refere Hall (2006) -, sua amargura parece consistir em marca de descentramento. Noutras palavras, uma espécie de pista para que o/a leitor/a possa inferir uma possível insatisfação sua com a realidade que a circunda.

Seja como for, parece que dentre os/as ancestrais do protagonista, foi a que menos deixou legados à família que ele edificou na América, distante que estava das possibilidades de transcendência suscitadas por sua condição de mulher oitocentista galega. O papel que ela desempenha no universo romanesco parece restringir-se ao tolhimento da sede de absoluto do marido Xan, cujo espírito aventureiro levava-o a "examinar a realidade como se a realidade assumisse o formato de uma caixa, em cujo interior nos mantínhamos prisioneiros" (Piñon, 1984, p. 391). Ela circunscreve a própria vida, e tenta circunscrever a dos que a rodeiam, nos limites dessa "caixa", como se não lhes fosse permitido sequer sonhar com quaisquer outras possibilidades. Se Xan ultrapassava, a sua revelia, esse limite - fosse por meio do ato de narrar aventuras alheias, fosse pela aventura que viveu, por dois anos, em outras paragens na companhia do amigo Salvador -, Ceferino, seu filho, não conseguiria "vencer a maldição da mãe" (p. 401):

- Se eu (Xan) falhei por não deixar as fronteiras espanholas, Ceferino irá triunfar em meu lugar. Ele irá para a América em meu nome, para me contar tudo depois, disse, esforçando-se em usufruir a presença de Teodora.

- Quer apostar comigo como ele não irá? E que farei o impossível para impedir? Saiba, Xan, que é assim que me vingarei de ti, disse a mulher, em tom monocórdio, sem crispar a voz (Piñon, 1984, p. 395).

Nesses fragmentos, ao falar em "vingança", Teodora autoriza o/a leitor/a a pensar no seu possível descentramento identitário: vingança contra o que, se, supostamente, rende tributo à realidade opressora? 
Quem sabe, contra o direito "natural" de o marido pleitear para si e para o filho varão a liberdade? Contra não lhe ser, sequer, permitido sonhar com a transposição das fronteiras espanholas e/ou daquelas impostas por sua condição de mulher galega oitocentista?

Essa amargura e insipidez de Teodora, "de quem Xan parecia guardar parcas lembranças", encontram seu contraponto em Urcesina, a mãe do protagonista. Observadas as proporções impostas por sua ambientação espaço-temporal, a esposa de Ceferino antecipa algumas nuanças da mulher contemporânea, capaz de impor suas opiniões e fazer-se respeitar. Sua atuação na narrativa assume considerável importância na medida em que funciona como um referencial fundamental na composição do caráter de Madruga e, consequentemente, de seus descendentes. Enquanto Xan contribui com parcelas relacionadas à valorização do sonho, às "miradas profundas", aos devaneios, à ânsia, enfim, de transcender fronteiras e oceanos, Urcesina, com os pés calcados firmemente na realidade, cobra-lhe atos. Segundo a ótica dessa extraordinária figura feminina, a possibilidade de entrar em conjunção com o sonho está vinculada a valores oriundos de estatutos concretos, como trabalho, economia, resistência física e moral, força, determinação, respeito etc.

Urcesina injetava no filho lições de realidade. Havia nela, contudo, a transcendência de um sentimento amoroso que unicamente o filho saberia exaltar. Aquela mulher, com estrita visão realista, transmitia-me porém expressiva fantasia. Suas palavras, na aparência destinadas a Madruga, eram de procedência arcaica, haviam nascido no campo espanhol, sob a inspiração galega. Por conseguinte arrastavam consigo marcas culturais que eu, sua descendente, não tinha o direito de dispensar (Piñon, 1984, p. 289).

O trecho acima consiste em uma reflexão de Breta, suscitada pela leitura de uma das cartas de Urcesina para Madruga, na qual faz constarem seus ensinamentos. $\mathrm{O}$ fato de essa mulher liberada, inserida em um contexto mais favorável a seu sexo, valorizar, como escritora, o perfil da bisavó parece-nos sintomático. Mais sintomático ainda é o fato de querer aplicar os conselhos dela a sua criação literária - incumbida que estava de transformar em romance a saga familiar. Trata-se de reconhecer-se a si própria e, quem sabe, sua mãe, Esperança, naquela mulher; trata-se, também, de reconhecer o próprio Madruga e, consequentemente, de compreendê-lo a partir dela:

Urcesina (...) aprendera a ir com seu jarro à fonte de águas turvas, que servia à sua aldeia, e batê-las contra a pedra para que 
clareassem. Dessa forma servindo-se delas com exemplar sabedoria milenar. Um fato ante o qual restava-me explorar os recursos à mão e que me facilitassem compreender uma mulher que havia gerado Madruga em meio à carência de sua aldeia, de sua região, do seu país, do seu continente.

De certo modo, Urcesina empurrou Madruga para a América. (...) E isto porque, apesar do tumulto das novas terras, não havia quem não capitulasse diante da sedutora América.

Sobretudo as mulheres que, ante o quadro da pobreza a lhes rondar a casa, aprontavam-se em expulsar os filhos. (...) Uma estranha união esta de mulheres e filhos, toda feita de sonhos encantatórios, frustrações, ambivalências (Piñon, 1984, p. 289).

Em certo sentido, essas ponderações da neta escritora de Madruga acerca de Urcesina, somadas a algumas outras atitudes suas que, ao lado dessas que falam de sabedoria, lucidez e coragem, falam de autoconfiança $^{3}$, de liderança ${ }^{4}$ e, entre outras coisas, de senso de realidade ${ }^{5}$ atrelado à necessidade de sonho, resumem o estatuto de mulher segundo o qual a galega se orienta.

No painel de figuras femininas do romance, Eulália, Esperança e Breta são centrais. A análise da evolução de suas trajetórias, segundo uma ordem cronológica, leva-nos a reconhecer, no conjunto, a mesma lógica que marcou a trajetória das conquistas sociais da mulher no século passado, viabilizadas pelo movimento feminista. Dito de outra forma, o modo como Eulália, Esperança e Breta foram construídas nos convida a fazer associações com o percurso histórico da mulher, galgado nos limites do século $X X$, rumo à sua emancipação - pelo menos a emancipação que pode ser atribuída a ela nos anos 1980 no Brasil.

Se, no caso de Eulália, o marido e o pai "haviam-lhe explicado a vida pela metade" (Piñon, 1984, p. 14), segundo a cartilha da ideologia patriarcal - daí a retração e a modéstia de seu comportamento, marcado, face às incongruências das relações de gênero, mais pela resistência que pela ação -, sua filha, Esperança, não se contentou com as meias verdades. Em

\footnotetext{
3 “Urcesina despreocupava-se com as moedas. Tinha certeza de que faltava ao marido a liberdade de gastá-las. Ainda que fosse para concretizar um sonho. Nem mesmo um terno para as festas da santa de Sobreira ele comprava, sem licença de Urcesina” (Piñon, 1984, p. 24).

4 "Urcesina gritava por ele. Repreendia os filhos, fazia a comida e escolhia que porco sacrificar no inverno" (p. 24).

5 “A mãe (...) jamais deixou de imprimir poesia à vida do filho. Sobretudo ao jogar Madruga no curral da realidade, premindo-o contra a parede, cobrando-lhe suor, lágrima e dinheiro. Para o filho regressar um dia triunfante. Um imperador romano, sem o estigma da morte, que sempre bafejou os que entravam em Roma no transporte da euforia popular” (p. 290-291).
} 
nome do sonho de viver a plenitude da vida, abdicou do conforto da casa paterna e lutou vorazmente por isto. Os frutos dessa luta ela não os pôde colher, mas os deixou de herança a Breta.

Em meio às personagens femininas que figuram no referido painel de perfis femininos, Eulália parece ser o símbolo da mulher-sujeito ${ }^{6}$ situada em épocas em que os germens do movimento feminista ainda não se faziam perceptíveis. Perceptíveis, apenas, eram os indícios da insustentabilidade do estado de coisas que então vigorava, relacionado aos desmandos da histórica dominação masculina.

Embora a natureza de Eulália não encontre lugar na realidade repressora do tempo, ela não se sente potente para se rebelar; trata-se de um reflexo da clara consciência que possui em relação à "inutilidade de competir com as vozes naturais" (Piñon, 1984, p. 14-15). Daí não demonstrar "urgência em alcançar qualquer canto da terra" e agir "como se não houvesse lugar onde pousar os pés" (p. 535). Daí resistir apenas passivamente, como quem inevitavelmente precisa cumprir uma jornada que, uma vez cumprida, abre espaço par o desfecho de sua trajetória, marcado pela decisão de morrer.

Essa decisão de Eulália, configurada como uma espécie de grito de independência, irônico por se realizar por meio da morte, revela definitivamente a disparidade existente entre sua realidade interior e a realidade do meio em que vivia. A esta, segundo suspeitas da própria personagem, faltava "um sentido realista"; isto é, em vez de ser construída segundo o desejo do indivíduo, contemplando a diferença, ela o é de acordo com códigos preestabelecidos no contexto histórico-cultural da sociedade patriarcal.

Essa realidade a que, segundo Eulália, falta "um sentido realista" obedece ao que Rita Schmidt (1999) chama de script básico feminino. No contexto em que a referida personagem se insere, esse script implica casamento, obviamente, com a preponderância do gênero masculino sobre o feminino, filhos, responsabilidades domésticas e, no máximo, acesso à religião. Faz parte do que Pierre Bourdieu (2005) chama de "dominação masculina", uma estrutura social estabelecida ao longo da história da humanidade e naturalizada, de acordo com os interesses da ideologia dominante responsável por sua construção. Segundo o sociólogo francês, "a força da ordem masculina se evidencia no fato de que ela dispensa

\footnotetext{
6 O termo "sujeito" ou "agente” subjaz às percepções femininas de sua identidade e de suas habilidades para assumir sua posição na sociedade e para refutar as atitudes e os pressupostos do patriarcalismo; a mulher-sujeito é marcada pela insubordinação aos seus paradigmas, por seu poder de decisão, dominação e imposição.
} 
justificação: a visão androcêntrica impõe-se como neutra e não tem necessidade de se enunciar em discursos que visem legitimá-la" (Bourdieu, 2005, p. 18). Os códigos sociais, portanto, ao alicerçarem-se sobre a dominação masculina, ratificam-na, entre outros fatores, por meio da divisão social/sexual do trabalho, da divisão social/sexual do espaço (rua/casa), da estruturação do tempo em constantes momentos de ruptura masculinos e longos períodos de gestação/amamentação/educação femininos.

Se a Eulália, e certamente à maioria das mulheres de seu tempo, não bastava cumprir tal roteiro para entrar em conjunção com a plenitude existencial, foi-lhe necessária uma vida inteira para conseguir, dada a força coercitiva do sistema, romper com esse estado de coisas. Na carência de outras armas, ela o faz, simbolicamente, por meio da decisão de morrer.

Ao construir essa personagem fazendo com que ela opte pela morte como reação à coerção das ideologias vigentes, Nélida Piñon desencadeia em $A$ república dos sonhos um processo de atos narrativos, continuados pelas outras personagens femininas do romance que compõem as gerações seguintes - que se traduz como subversão do script imposto pelo contexto histórico-cultural legitimador da dominação masculina, referida por Bourdieu (2005), bem como pelos códigos estético-ideológicos que regem a literatura canônica.

Em relação a estes últimos, como bem pondera Schmidt, as leis que regem o casamento, a sexualidade e a dependência feminina, nos romances canônicos do século XIX, são insistentes a ponto de se poderem identificar sequências narrativas recorrentes, como casamento, adultério, loucura e morte. Trata-se de um "aparato ideológico dirigido à socialização das personagens femininas dentro de limites legais, econômicos e sexuais, inscrevendo os desejos individuais num código coletivo de ações, cujas sequências reforçam comportamentos psiquicamente introjetados e papéis socialmente legitimados" (Schmidt, 1999, p. 673).

Se a morte e a loucura, nesses romances - que se constituem no lugar par excellence da articulação ideológica do sistema de gênero -, ocorrem como resoluções narrativas nos casos em que as personagens femininas transgridem os limites e violam os valores do universo ideológico-familiar, a morte na trajetória de Eulália assume outra roupagem: um grito de "basta", após décadas de resignação e de resistência.

Tendo em vista o núcleo galego de personagens femininas que compõem o romance, composto por Teodora, Urcesina e Eulália, a trajetória desta última parece encerrar um ciclo, marcado por ancestrais práticas e comportamentos femininos arraigados na tradição patriarcal. Nessas representações de mulheres espanholas, inseridas entre as últimas décadas 
do século XIX e as primeiras do XX, ao tão recorrente script feminino referido - casamento, filhos e responsabilidades domésticas - somam-se, sub-repticiamente, certas marcas e/ou estratégias de sobrevivência ante a opressão a que estão sujeitas: rendição à amargura, vislumbrada no empenho em cercear os sonhos do Outro ${ }^{7}$ como forma de igualá-lo a si na dor (Teodora); a força produtiva empenhada em reverter situações disfóricas e realizar sonhos, ainda que sejam os alheios (Urcesina); por fim, a resistência passiva frente às intempéries da vida, num certo sentido, anulada pelos valores patriarcais (Eulália). Essas estratégias funcionam como espécies de resposta à opressão silenciosa, chamada por Bourdieu (2005) de dominação/violência simbólica, uma dominação estruturada de tal forma que é capaz de levar as próprias mulheres a contribuírem para com a própria exclusão e subordinação, entendidas como inevitáveis. Daí elas responderem, por vezes, com práticas e comportamentos também simbólicos como esses acima referidos.

Partindo da análise do modo como as estruturas de dominação da ordem social masculina se estabelecem na sociedade cabila, Bourdieu (2005) defende a tese de que tais estruturas resultam de um trabalho incessante de reprodução de estratégias e práticas calcadas na divisão bipolar dos sexos em dominado e dominante, de tal forma que o polo dominante é o masculino. Entre as estratégias e práticas apontadas como determinantes da construção social dos corpos e, consequentemente, da incorporação da dominação masculina, é fundamental a estratégia da naturalização do construído. Concorrem para com ela instituições como Família, Estado, Igreja e Escola, entendidas como lugares de elaboração e imposição de princípios de visão e divisão sexualizantes veiculados pelo corpo, ratificadores da dominação masculinae que são "vendidos" como naturais. Eis o que parece alicerçar a trajetória dessas figuras femininas, construídas como integrantes da cultura galega na passagem do século XIX ao XX.

$O$ grupo de mulheres inseridas no espaço cultural brasileiro de meados do século XX em diante - Esperança e Breta - também é influenciado pela dominação masculina e a violência simbólica definidas pelo sociólogo francês. No entanto, diferentemente do grupo galego, encontram

\footnotetext{
${ }^{7}$ Na teoria lacaniana, há o outro e o Outro: o outro significa o que não é realmente o outro, mas uma projeção e uma reflexão acerca dele; o Outro significa a alteridade radical não reduzida a nenhuma significação imaginária ou subjetiva. Desse modo, a comparação de uma pessoa ou grupo (mulheres/ negros) como o outro significa a posição fora do sistema da "normalidade" ou do centro, ou seja, a margem; o Outro pode ser comparado com o patriarcalismo ou com aquele que profere o discurso patriarcal.
} 
no contexto em que se inserem condições favoráveis para que possam responder à opressão de forma mais incisiva e evidente.

A morte de Esperança, ao final de sua longa trajetória marcada por inúmeras guerrilhas contra o sistema patriarcal, não é concebida, no universo narrativo, como punição às transgressões que ela opera em relação aos códigos norteadores do sistema de gênero; mas também não o é apenas como consequência de um estágio de vida em que a tolerância, em face da insatisfação frente à realidade opressora, atinge uma situação-limite, como ocorre com Eulália. Seu suicídio vem coroar, em uma última manifestação, o final da longa e árdua batalha, que sucedeu sua expulsão da casa paterna, contra a teia de instituições e práticas sociais que o sistema de gênero envolve, como a divisão sexual do trabalho, a representação de papéis sexuais rígidos, a supervalorização do casamento e as limitações no que toca à expressão de escolhas, da sexualidade e do desejo feminino.

Esperança, portanto, situada na geração posterior a Eulália, no contexto cultural brasileiro, é marcada por um estágio de conscientização mais adiantado e - apesar de ainda não contar com o suporte histórico-social, erigido nos anos posteriores com o feminismo, capaz de lhe garantir uma luta respaldada -, levantou a bandeira da insubordinação, protestando e rompendo com os modelos e valores dominantes.

O resultado foi seu relativo "enquadramento" na Lei do Pai; relativo porque, se a ela não foi permitido viver sua escolha com serenidade - já que a solidão, o abandono e a pressão social supostamente a conduziram à morte, entendida como um último argumento -, ela pôde, ao menos, "dar o seu recado". Isso implica dizer que a sua trajetória fez com que fosse enfaticamente registrada a insatisfação que nutria no tocante à ideologia patriarcal, que é, no fim, a insatisfação da mulher a ela contemporânea; mais que isso, promoveu o desnudamento do fato de que a mulher não sucumbiria, incondicionalmente, por muito mais tempo, a essa ideologia em voga por milênios.

Em vista disso, podemos dizer que, em A república dos sonhos, Piñon toma o modelo feminino concebido ideologicamente pelo patriarcalismo como um parâmetro a partir do qual executa deslocamentos semânticos, entendidos como o lugar da resistência que caracterizaria a alteridade da literatura de autoria feminina.

Na trajetória de Esperança, o parâmetro a partir do qual a escritora opera a maioria dos deslocamentos semânticos é o casamento, tomado como uma instituição legitimadora do exercício sexual e da procriação. A reflexão abaixo, de Schmidt, contempla o significado dessa instituição no universo romanesco, considerado de forma ampla: 
Como aponta Leo Bersani, "na tradição do romance moderno, o casamento completa o sentido", mesmo quando não figure como uma resolução, seja feliz ou infeliz. Sua importância não é puramente formal, uma vez que imprime na narrativa uma estrutura significante que traduz um modo de produção de relações sociais altamente valorizadas e coerentes com a visão de um mundo capitalista e burguês, cujo discurso moralizante está centrado no valor da domesticidade a partir da naturalização da mulher no espaço "sagrado" do lar (Schmidt, 1999, p. 673).

Esse apontamento faz emergir a vastidão do deslocamento semântico que o modo de construção de Esperança implica, em relação ao modelo de comportamento estabelecido pela ideologia patriarcal, corriqueiramente representado nas narrativas romanescas. Ao manter relações amorosas com um homem casado, engravidar dele e, após ser banida da casa paterna, ter a filha e viver com ela por sua conta e risco, Esperança contraria todas as expectativas do senso-comum, em face do qual esse modo de gerir a vida assume os foros do não senso.

Do ponto de vista do pensamento feminista, todavia, esse modo com que Esperança é idealizada pela escritora aponta para a criação de um espaço, dentro dos discursos patriarcais, capaz de propiciar a visualização da mulher como agente ativo de sua história, e não simplesmente como objeto passivo, sujeito a toda sorte de subjugação.

Quanto a Breta - a terceira personagem que vem compor, junto com Eulália e Esperança, o trio das personagens femininas que nos parece ilustrar a trajetória da emancipação feminina -, outro status quo em relação à condição social da mulher lhe respaldou as ações. Ela está ambientada no Brasil a partir dos anos 1960, momento histórico marcado por significativas revoluções culturais que, de certa forma, facilitaram-lhe a desestruturação do patriarcalismo dominante no seio da família do avô Madruga.

Ela representa, no universo romanesco, a mulher que encontrou, a partir do pensamento feminista reinante em seu tempo, condições para escapar da dependência e da submissão milenar de seu sexo. Trata-se de estar em conjunção com uma liberdade que não fora, sequer, sonhada pela geração de sua avó Eulália. E, se a geração de sua mãe ousou fazê-lo, fê-lo como pioneira que era da transgressão. Como tal, teve de se submeter, como no caso da própria Esperança, às calúnias e à exclusão da sociedade.

A trajetória de Breta, portanto, examinada em relação às trajetórias de Eulália e Esperança, surge em A república dos sonhos como uma etapa fundamental do ciclo que descreve o processo de emancipação da mulher. 
Nessa etapa, em vez de nos depararmos com uma figura feminina enredada no sistema de gênero, do qual a mulher sempre fora prisioneira, como bem atestam as trajetórias de suas ancestrais galegas, deparamo-nos com uma mulher liberada, com direito à voz e vez no universo social em que é ambientada. Sua postura social se configura a partir de constantes deslocamentos semânticos operados em relação aos valores embutidos no sistema de gênero. Assim acontece no âmbito das relações amorosas, em que ela repudia o casamento como instituição altamente valorizada no mundo patriarcal, capitalista e burguês. Ocorre também no âmbito de suas crenças político-ideológicas, já que, no auge da ditadura militar, ela se compromete com grupos de esquerda, fazendo-se respeitar pelos que a cercam; e no âmbito profissional, em que se faz escritora, profissão tradicionalmente masculina, imbuída do direito de narrar segundo uma ótica revisionista, crítica e racional. E acontece, principalmente, no âmbito familiar, em que consegue introjetar novos pontos de vista no que concerne às convenções sociais, incluindo os papéis femininos.

Segundo essa linha evolutiva, pode-se ler o modo de construção desse trio de personagens femininas como sendo capaz de historicizar a condição social da mulher, incorporando-lhe mudanças e aceitando-lhe a transitoriedade, sem perder de vista as condições concretas que a acompanham. Daí dizermos que suas trajetórias desenvolvem-se em consonância ao desenvolvimento das conquistas emancipadoras da mulher.

Nesse sentido, ao trazer a história da evolução da condição social da mulher para o universo da ficção, Piñon o faz inscrevendo-a na linhagem do pensamento feminista empenhada na desconstrução de gênero ou na subversão de modelos culturais cristalizados que oprimem e excluem sujeitos. Para Judith Butler (2001), a principal representante dessa linha de pensamento, o gênero implica assumir um modo de viver o corpo no mundo; trata-se de um ato de interpretação da realidade cultural sancionadora. Tomando como ponto de partida a desconstrução de Derrida e a psicanálise de Freud e Lacan, ela rompe com o sistema sexo-gênero, eliminando seu marco binário, apoiada na tese de que os corpos não se adaptam às normas segundo as quais sua materialização é imposta. O gênero é concebido face ao construto cultural imposto sobre a superfície da matéria, ou seja, o corpo, o sexo; o gênero absorve e desloca o sexo, cuja ideia é produzida, e também desestabilizada, no curso da reiteração das normas sociais. Nesse sentido, a opressão da mulher e a inferioridade a ela atribuída não são inerentes à sua natureza, mas construídas, paulatinamente, ao longo da história cultural. Não sendo naturais, e considerando o empenho da própria mulher em desestabilizá-las, há que se substituírem 
as abordagens e/ou representações de seu processo histórico alicerçadas na permanência, por outras que focalizem conjunturas provisórias e concretas, transcendendo definições estáticas e desconstruindo categorias abstratas.

Se a mulher, na maior parte de sua história, esteve atada ao peso das convenções, dos papéis sociais e do determinismo de sexo, conforme retrata a trajetória de Eulália e, de forma menos estável, a de Esperança, essa situação nas últimas décadas tem assumido novo perfil. Há, portanto, que fazer refletir esse novo estado de coisas na literatura, sobretudo, se não há intenção de eternizar a "condição" de subjugada da mulher. Se representar implica construir o gênero e seus papéis, como defende Teresa de Laurettis em a "Tecnologia do gênero" (1994), Nélida Piñon, em A república dos sonhos, ao retratar a história da mulher por meio desse movimento ascendente, que culmina na construção de uma personagem como Breta, propõe uma drástica mudança de rumos. Representa/constrói imagens femininas condizentes com o tempo em que elas se inserem; no caso de Breta, anárquico por excelência.

As representações interculturais de gênero empreendidas nesse importante romance brasileiro de autoria feminina, ambientadas na Espanha do século XIX e início do XX e no Brasil dos anos 1920 em diante, caminham na contramão das clássicas representações femininas empreendidas na literatura canônica ocidental, de modo especial, na brasileira. Ao invés das Lucíolas e Iracemas ${ }^{8}$, das Capitus ${ }^{9}$, das Efigênias ${ }^{10}$ e das Madalenas ${ }^{11}$, figuras femininas estereotipadas, representadas a partir dos códigos que regem os papéis femininos no interior do patriarcado, identidades femininas mais próximas daquelas que povoam nossa realidade, expressamente constituída a partir da pluralidade e da heterogeneidade.

Se as figuras femininas do núcleo galego a que nos referimos - Teodora, Urcesina e Eulália - aparecem marcadas por intensos reflexos da ideologia patriarcal, condizentes com o contingente cultural daquele contexto, ainda assim suas trajetórias apresentam marcas de inconformismo, seja por meio da amargura da primeira, do espírito prático com que a segunda cuida da casa e dos projetos da família a fim de garantir ao filho um destino diferente do seu, ou da resistência da última, que, ao intuir a "inutilidade

\footnotetext{
${ }^{8}$ Referentes às protagonistas dos romances homônimos do escritor romântico brasileiro José de Alencar.

${ }^{9}$ Referente à protagonista de Dom Casmurro, romance realista escrito por Machado de Assis.

${ }^{10}$ Referente à personagem de Triste fim de Policarpo Quaresma, romance pré-modernista escrito por Lima Barreto.

${ }^{11}$ Referente à protagonista de São Bernardo, romance da segunda geração modernista, escrito por Graciliano Ramos.
} 
de lutar contra as vozes naturais como o trovão e a tormenta", gerencia, dos bastidores da casa, a convivência familiar, apaziguando os ânimos.

Nesse cenário, mais que contribuir para a construção excludente e bipolar do gênero, nos termos de Butler (2003), tais representações femininas, ao sinalizarem para a insatisfação que lhes permeia a existência, parecem preparar o terreno para as gerações seguintes, cujas trajetórias indubitavelmente por si concorrem para a construção de uma nova mentalidade no que se refere às relações de gênero, com ênfase no modo de estar da mulher na sociedade. Assim é que o núcleo brasileiro das principais personagens que integram o romance, constituído por Esperança e Breta, propõe um novo estatuto para a mulher, no qual figuram mais que o direito à voz, o direito de gerir a própria vida, quaisquer que sejam as escolhas.

Falar, portanto, nas representações interculturais de gênero empreendidas em $A$ república dos sonhos, implica reconhecer o diálogo que o romance estabelece, de um lado, com a ideologia dominante que marginaliza a mulher - o patriarcado - e, de outro, com o feminismo, que, por meio das diversas "ondas" por que vem passando desde os seus primórdios (cf. Duarte, 2004), advoga a igualdade de direitos entre os sexos e luta contra a discriminação da mulher, desestabilizando a ordem masculina, unilateral. Respeitada a discrepância temporal e cultural que separa o núcleo galego do brasileiro, bem como o descentramento e a heterogeneidade das personagens no interior de cada um dos grupos, a interface dessas representações recai sobre o desejo, contido ou não, de transcendência que nelas se vislumbra. Nesta saga familiar que nasce na Galícia e se desdobra no Brasil, a república dos sonhos de tanta gente, espanholas e brasileiras são unificadas no prazer e na dor de viverem e "desviverem" o que consideram ser a própria identidade.

\section{Referências}

BOURDIEU, Pierre (1998). A economia das trocas linguísticas: o que falar quer dizer. Trad. Sérgio Miceli et al. 2. ed. São Paulo: Edusp. (2005). A dominação masculina. Trad. Maria Helena Küher. 4. ed. Rio de Janeiro: Bertrand Brasil.

BUTLER, Judith (1988). "Posições do sujeito, atuações de gênero". In: BESSA, K. A. Estudos feministas. Rio de Janeiro: IFCS/UFRJ, v. 6, n. 2.

(2001). "Corpos que pesam: sobre os limites discursivos do 'sexo'". In: LOURO, Guacira Lopes (Org.). O corpo educado: pedagogias da sexualidade. Belo Horizonte: Autêntica.

(2003). Problemas de gênero: feminismo e subversão da identidade. Rio de Janeiro: Civilização Brasileira. 
CHARTIER, Roger (1990). A história cultural. Rio de Janeiro: Bertrand. DUARTE, Constância Lima (2004). “Literatura e feminismo no Brasil: primeiros apontamentos". In: MOREIRA, Nadilza Martins de Barros (Org.). Mulheres no mundo: etnia, marginalidade e diáspora. João Pessoa: Idéia.

GINZBURG, Carlo (2001). Olhos de madeira: nove reflexões sobre a distância. São Paulo: Companhia das Letras.

HALL, Stuart (2006). A identidade cultural na pós-modernidade. Trad. Thomas Tadeu da Silva e Guacira Lopes Louro. 11. ed. Rio de Janeiro: DP\&A.

LAURETTIS, Teresa de (1994). "A tecnologia do gênero". In: HOLLANDA, Heloisa Buarque de (Org.). Tendências e impasses. Rio de Janeiro: Rocco.

MILLETT, Kate (1970). Sexual politics. Garden City: Doubleday.

PIÑON, Nélida (1984). A república dos sonhos. Rio de Janeiro: Francisco Alves. PROENÇA FILHO, Domício (1998). "A inquieta ficção de uma mulher cidadã e escritora". Folha de S. Paulo, São Paulo, Ilustrada, p. 4, 26 de setembro.

SCHMIDT, Rita T. (1999). "A transgressão da margem e o destino de Celeste". In: SEMINÁRIO NACIONAL MULHER E LITERATURA, 7., Anais... Niterói: EdUFF, p. 672-82.

ZOLIN, Lúcia Osana (2003). Desconstruindo a opressão: a imagem feminina em A república dos sonhos, de Nélida Piñon. Maringá: Eduem.

Recebido em junho de 2011.

Aprovado em outubro de 2011.

\section{resumolabstract}

Representações interculturais de gênero no romance $A$ república dos sonhos, de Nélida Piñon

Lúcia Osana Zolin

O romance A república dos sonhos (1984), da escritora brasileira Nélida Piñon, empreende representações de gênero ambientadas, por um lado, em uma Galícia de inspiração medieval e de tradição oral, terra de peregrinações e de emigrantes. Por outro lado, as representações de gênero ambientadas no Brasil do século XX constituem um interessante painel da trajetória da emancipação da mulher, galgada a partir dos movimentos feministas. O romance, nesse sentido, integra o processo de implantação de vozes dissonantes em relação a ideologias dominantes como o patriarcalismo e o falogocentrismo, comumente representadas e reduplicadas na literatura canônica. Trata-se de inscrever, no lugar da tradicional identidade feminina, fixa e presa aos papéis de gênero, estabelecidos pelo pensamento patriarcal, a multiplicidade e a heterogeneidade, portanto, o descentramento de identidades, por meio da intersecção com múltiplas outras questões como raça, etnia, classe e orientação sexual. Fundamentando nossa investigação no feminismo crítico e, de modo geral, no pós-estruturalismo, nosso propósito é empreender uma discussão acerca do modo como a escritora, em diálogo com a tradição espanhola, 
representa identidades femininas, bem como, as relações de gênero nesse importante romance do século XX.

Palavras-chave: gênero, representação, personagem feminina, Espanha, Brasil.

\section{Intercultural representations of gender in the novel A república dos sonhos, by Nélida Piñon}

Lúcia Osana Zolin

Brazilian author Nélida Piñon's novel A república dos sonhos (The Republic of Dreams) (1984) engages, on the one hand, gender representations of a medievalinspired Galicia, with its oral traditions, pilgrimages and emigrants. On the other hand, the gender representations in $20^{\text {th }}$ century Brazil provide a highly interest view of female emancipation brought about by feminist movements. The novel reveals the process of discordant voices with regard to hegemonic ideologies such as patriarchy and phallogocentrism commonly represented and replicated in canonical literature. Instead of the traditional feminine identity characterized and fixed by patriarchy-established gender female roles, she inscribes multiplicity and heterogeneity. In other words, the decentralization of identities intersects with other issues such as race, ethnicity, class and sexual orientation as constitutive of the contemporary Brazilian society. Foregrounded on concepts from critical feminism and post-structuralism, a discussion ensues on the way a contemporary Brazilian female writer, dialoging with Spanish tradition, represents feminine identities and gender relationships in this important $20^{\text {th }}$ century novel.

Keywords: gender; representation; female character; Spain; Brazil. 